\title{
Forest and shrubland canopy carbon uptake in relation to foliage nitrogen concentration and leaf area index: a modelling analysis
}

\author{
David WHITEHEAD ${ }^{\mathrm{a} *}$, Adrian S. WALCROFT ${ }^{\mathrm{b}}$ \\ a Landcare Research, PO Box 69, Lincoln 8152, New Zealand \\ ${ }^{\mathrm{b}}$ Landcare Research, Private Bag 11052, Palmerston North, New Zealand
}

(Received 2 August 2004; accepted 8 March 2005)

\begin{abstract}
A multi-layer canopy model was used to simulate the effects of changing foliage nitrogen concentration and leaf area index on annual net carbon uptake in two contrasting indigenous forest ecosystems in New Zealand, to reveal the mechanisms regulating differences in light use efficiency. In the mature conifer-broadleaved forest dominated by Dacrydium cupressinum, canopy photosynthesis is limited principally by the rate of carboxylation associated with low nutrient availability. Photosynthesis in the secondary successional Leptospermum scoparium/Kunzea ericoides shrubland is limited by electron transport. Maximum carbon uptake occurred in spring at both sites. Annual increases in canopy photosynthesis with simulated increases up to $50 \%$ in leaf area index, $L$, or foliage nitrogen concentration per unit foliage area, $N_{\mathrm{a}}$, were largely offset by increases in night-time respiration. A realistic simulation where $L$ was increased by $50 \%$ and $N_{\mathrm{a}}$ by $20 \%$ together (equivalent to an increase in total canopy nitrogen of $80 \%$ ) led to decreases in net annual carbon uptake because the increase in photosynthesis was offset by the increase in respiration. Given the environmental constraints, both canopies in their natural states appear to be operating at the optimum conditions of leaf area index and nitrogen concentration for maximum net carbon uptake.
\end{abstract}

photosynthesis / respiration / leaf area index / nitrogen / light use efficiency

Résumé - Assimilation de carbone par une canopée forestière et une végétation buissonnante en relation avec l'indice foliaire et les teneurs en azote : un exercice de modélisation. Un modèle multi couche de canopée forestière a été utilisé pour simuler les effets de changements des teneurs en azote foliaire et d'indice foliaire sur le bilan net annuel d'assimilation de carbone dans deux écosystèmes forestiers contrastés de Nouvelle Zélande, afin de révéler les mécanismes de régulation et de contrôle d'efficience d'utilisation de la lumière par les canopées. Dans la forêt primaire mixte conifère feuillue dominée par Dacrydium cupressinum, l'assimilation de carbone de la canopée est limité par la carboxylation, essentiellement du fait d'une faible disponibilité en éléments minéraux. Cette assimilation est limitée par le transport d'électrons photosynthétiques dans le cas du peuplement buissonnant secondaire à base de Leptospermum scoparium/Kunzea ericoides. Le maximum d'assimilation de carbone se produit au printemps dans les deux cas. Au cours de l'année, les gains induits dans la photosynthèse par des augmentations simulées d'indice foliaire de $50 \%$ ont été largement contrebalancés par les pertes dues à l'augmentation de respiration nocturne. Une simulation réaliste dans laquelle l'indice foliaire était augmenté de $50 \%$ et l'azote foliaire de $20 \%$ (ce qui correspond à une augmentation de $10 \%$ de l'azote total de la canopée) a conduit à une baisse du gain de carbone cumulé sur l'année. Étant données les contraintes imposées par l'environnement, les deux couverts semblent fonctionner à l'optimum de leur indice foliaire et de leur concentration en $\mathrm{N}$ et maximisent ainsi le gain annuel de carbone.

photosynthèse / respiration / index foliaire / azote / efficience d'utilisation de la lumière

\section{INTRODUCTION}

In New Zealand, indigenous forests occupy $59 \times 10^{3} \mathrm{~km}^{2}$ $(23 \%)$ of the land area and they comprise the largest national vegetation carbon reservoir (940 Mt C) [51]. There is increasing interest in shrublands, in particular, because of the potential for large areas of hill country that have become uneconomic for pastoral farming to revert to shrublands. The resulting uptake and storage of carbon could provide an important additional sink at the national scale [51]. However, most sites with poten- tial for carbon storage are where soil fertility is low. To quantify the potential amount of carbon storage in forests and to predict future changes in relation to environmental factors or management, it is necessary to determine the rates of carbon uptake and storage by different forest types and to identify the factors regulating carbon uptake.

There are many examples where the addition of fertiliser to managed forests results in an increase in productivity [1, 15, $44,46]$ and analysis using models has identified nutrient availability as a major source of variation in productivity [27, 39].

\footnotetext{
* Corresponding author: whiteheadd@landcareresearch.co.nz
} 
Table I. Measured maximum values of the maximum rate of carboxylation, $V_{\mathrm{cmax}}$, the apparent maximum rate of electron transport at saturating irradiance, $J_{\max }$, rate of photosynthesis at saturating irradiance, $A_{\max }$, and stomatal conductance, $g_{\mathrm{s}}$, in relation to foliage nitrogen concentration on a mass basis, $N_{\mathrm{m}}$, and specific leaf area, $S$, for forest species indigenous to New Zealand. All values are expressed on a half-total surface area basis.

\begin{tabular}{|c|c|c|c|c|c|c|c|c|}
\hline Species & 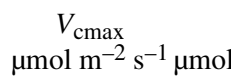 & $\begin{array}{l}J_{\max } \\
1 \mathrm{E} \mathrm{m}^{-2} \mathrm{~s}^{-1}\end{array}$ & $J_{\max }: V_{\mathrm{cmax}}$ & 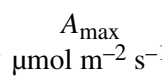 & $\begin{array}{c}g_{\mathrm{s}} \\
1 \mathrm{mmol} \mathrm{m}^{-2} \mathrm{~s}^{-1}\end{array}$ & $\begin{array}{c}N_{\mathrm{m}} \\
\mathrm{mmol} \mathrm{kg}^{-1}\end{array}$ & $\begin{array}{c}S \\
\mathrm{~m}^{2} \mathrm{~kg}^{-1}\end{array}$ & Source \\
\hline Nothofagus solandri var. cliffortioides & 75 & 142 & 1.9 & 10.0 & 200 & 0.75 & 5.0 & {$[4,22,41]$} \\
\hline Fuschsia exorticata & 54 & 128 & 2.4 & 14.5 & 300 & 1.78 & 14.3 & [9] \\
\hline Aristotelia serrata & 52 & 115 & 2.2 & 14.6 & 250 & 1.51 & 11.1 & [9] \\
\hline $\begin{array}{l}\text { Leptospermum scoparium } \\
\text { Kunzea ericoides }\end{array}$ & 47 & 94 & 2.0 & 10.8 & 394 & 1.25 & 7.6 & [59] \\
\hline Meterosideros umbellata & 46 & 193 & 4.2 & 13.0 & 281 & 0.72 & 4.2 & {$[51]$} \\
\hline Nothofagus fusca & 38 & 101 & 2.7 & 12.3 & 250 & 1.96 & 13.5 & {$[20,23]$} \\
\hline Quintinia acutifolia $^{1}$ & 17 & 50 & 2.9 & 5.7 & 107 & 0.82 & 8.4 & {$[51]$} \\
\hline Weinmannia racemosa ${ }^{1}$ & 13 & 49 & 3.8 & 2.9 & 44 & 0.75 & 6.1 & {$[51]$} \\
\hline Dacrydium cupressinum & 12 & 32 & 3.3 & 2.7 & 46 & 1.06 & 8.3 & {$[51]$} \\
\hline
\end{tabular}

${ }^{1}$ Growing as understorey species.

Physiologically, addition of fertiliser initiates processes that lead to larger pools of proteins in foliage that increase photosynthesis and promote nitrogen translocation for enhanced foliage growth [17]. The most pronounced result when nitrogen fertiliser is added is an increase in leaf area index, $L,[1,5,15$, $18,54]$. This is accompanied by an increase in the rate of photosynthesis, $A$, at the leaf and canopy scales, but the size of this response is usually much less than the effects on $L[33,48,49]$. Further, the combined effects of increases in self-shading, and rates of night-time respiration associated with increased foliage area [42], may result in only small increases in net carbon uptake at the canopy scale $[7,26,36]$.

Much less work has been undertaken to investigate the potential for increasing productivity by adding fertiliser to unmanaged, indigenous canopies. However, evidence from modelling approaches shows that productivity in mature forests $[57,58]$ and shrublands [56] in New Zealand is limited principally by low nutrient availability.

An increase in photosynthetic capacity with increasing foliage nitrogen concentration is anticipated because of the high proportion of nitrogen in foliage in the carboxylating enzyme Rubisco $[11,14]$ and positive relationships between photosynthesis and foliage nitrogen concentration have been reported for a wide range of broadleaved evergreen species [19], broadleaved deciduous species [9, 52, 62] and conifers [55]. However, rates of respiration also increase with increasing foliage nitrogen concentration because of the greater need for maintenance and repair processes in cells $[42,43]$.

In this paper we use a modelling approach to investigate the effects of increasing $L$ and foliage nitrogen concentration per unit area, $N_{\mathrm{a}}$, on annual net canopy photosynthesis, integrating the effects on daily photosynthesis and night-time respiration, for two contrasting indigenous forest canopies in New Zealand. To allow comparison between the canopies, we present the results in terms of the effects on annual light use efficiency. We define gross light use efficiency as the ratio of annual daytime net canopy photosynthesis, $A$, and annual solar irradiance (400$700 \mathrm{~nm})$ absorbed by the canopy, $Q_{\mathrm{a}},\left(\varepsilon_{\text {gross }}=A / Q_{\mathrm{a}}\right)$, and net light use efficiency as the ratio of the difference between annual net canopy photosynthesis and foliage night-time respiration, $R_{\mathrm{d}}$, and annual absorbed irradiance $\left(\varepsilon_{\text {net }}=\left[A-R_{\mathrm{d}}\right] / Q_{\mathrm{a}}\right)$. Our objective was to explore the sensitivity of the response of canopy carbon uptake to changes in leaf area index and foliage nitrogen concentration for the two canopies. The conclusions are based on simulated results using a canopy model. While we are unable to validate the outputs from the model using experimental observations, we anticipated that the analysis would provide useful interpretation of the processes limiting canopy carbon uptake in the natural growing conditions. To provide perspective for the analysis, we begin by reviewing data on rates of photosynthesis at the leaf scale in relation to nitrogen concentration and light use efficiency at the canopy scale for woody species indigenous to New Zealand.

\section{REVIEW OF DATA FOR NEW ZEALAND FORESTS}

Few data are available for the photosynthetic properties of tree species indigenous to New Zealand, but those that have been measured show that there is a wide range in maximum rates of photosynthesis and stomatal conductance (Tab. I) [24, 57]. Consistent with this is the range in the values of the parameters describing the processes limiting photosynthesis: maximum rates of carboxylation, $V_{\mathrm{cmax}}$, and the apparent maximum rate of electron transport at saturating irradiance, $J_{\max }$. While values for broadleaved species on fertile sites are as high as those found in northern hemisphere deciduous forests, values for indigenous conifers and understorey species are lower than those for northern hemisphere coniferous species [25, 64]. For most of the species where measurements are available, values of the ratio $J_{\max }: V_{\mathrm{cmax}}$ are close to the average value at $20^{\circ} \mathrm{C}$ of 2.7 reported for a wide range of species [31]. However, higher values of the ratio have been measured for some species and this is attributable to low values of $V_{\text {cmax }}$, consistent with low foliage nitrogen concentrations (Tab. I). These data suggest that rates of photosynthesis at the leaf scale in indigenous species in New Zealand are likely to be very variable, and that 
Table II. Estimates of annual light use efficiency for indigenous forests in New Zealand using the multi-layer canopy model described in the text. The symbols refer to $L$, effective leaf area index (half-total surface area basis); $Q_{\mathrm{i}}$ annual incident irradiance (400-700 nm); $Q_{\mathrm{a}}$ irradiance absorbed by the canopy, $\varepsilon_{\text {gross }}$, gross and $\varepsilon_{\text {net }}$, net annual light use efficiency; $A$ annual net canopy photosynthesis; and $R_{\mathrm{d}}$, annual night-time respiration.

\begin{tabular}{|c|c|c|c|c|c|c|c|c|}
\hline Species & Site & $\begin{array}{l}\text { Latitude, } \\
\text { longitude }\end{array}$ & $\begin{array}{c}L \\
\mathrm{~m}^{2} \mathrm{~m}^{-2}\end{array}$ & $\begin{array}{c}Q_{\mathrm{i}} \\
\mathrm{kmol} \mathrm{m}^{-2}\end{array}$ & $Q_{\mathrm{a}} / Q_{\mathrm{i}}$ & $\begin{array}{c}\varepsilon_{\text {gross }}^{1} \\
\mathrm{gC} \mathrm{MJ}^{-1}\end{array}$ & $\begin{array}{c}\varepsilon_{\mathrm{net}}^{2} \\
\mathrm{gC} \mathrm{MJ}^{-1}\end{array}$ & $\begin{array}{l}\text { Data } \\
\text { source }\end{array}$ \\
\hline Nothofagus solandri & Craigieburn Forest & $43.2^{\circ} \mathrm{S}, 172.0^{\circ} \mathrm{E}$ & 6.0 & 9.23 & 0.85 & 1.14 & 1.09 & [41] \\
\hline Nothofagus fusca ${ }^{3}$ & Maruia Forest & $42.2^{\circ} \mathrm{S}, 172.3^{\circ} \mathrm{E}$ & 7.3 & 10.15 & 0.91 & 0.99 & 0.83 & \\
\hline $\begin{array}{l}\text { Leptospermum scoparium } \\
\text { Kunzea ericoides }\end{array}$ & Tongariro National Park & $39.5^{\circ} \mathrm{S}, 175.8^{\circ} \mathrm{E}$ & 2.8 & 9.58 & 0.76 & 0.94 & 0.72 & [59] \\
\hline $\begin{array}{l}\text { Aristotelia serrata } \\
\text { Fuschsia exorticata }\end{array}$ & Taramakau River & $42.8^{\circ} \mathrm{S}, 171.6^{\circ} \mathrm{E}$ & 5.4 & 8.14 & 0.86 & 0.72 & 0.53 & [10] \\
\hline Dacrydium cupressinum & Okarito Forest & $43.2^{\circ} \mathrm{S}, 170.3^{\circ} \mathrm{E}$ & 3.5 & 10.74 & 0.78 & 0.46 & 0.27 & [58] \\
\hline
\end{tabular}

${ }^{1} \varepsilon_{\text {gross }}=A / Q_{\mathrm{a}}$.

${ }^{2} \varepsilon_{\text {net }}=\left(A-R_{\mathrm{d}}\right) / Q_{\mathrm{a}}$.

${ }^{3}$ Unpublished data.

photosynthesis in some species is limited principally by low nutrient availability and low values of $V_{\mathrm{cmax}}$ [57].

For canopies, photosynthesis is regulated by both rates of photosynthesis at the leaf scale and canopy properties, principally leaf area index, $L$, and its effect on radiation interception. We have previously used the multi-layer canopy model described later in this paper to estimate annual light use efficiency for five forest canopies in New Zealand where meteorological data and values for parameters in the model are available. Leaf area index in these forests varied from 2.8 to 7.3 , but the range in the fraction of incident irradiance absorbed by the canopies was smaller, from 0.76 to 0.91 (Tab. II). Rainfall at all these sites is sufficient such that root-zone water deficits sufficient to limit canopy photosynthesis are restricted to short periods in summer. Results from the model suggest that there is a wide range in light use efficiency of canopy photosynthesis $\left(\varepsilon_{\text {gross }}\right)$ with the range increasing when foliage night-time respiration is included $\left(\varepsilon_{\text {net }}\right)$ (Tab. II).

For the purposes of this paper we selected two contrasting canopies to simulate the effects of decreases and increases in $N_{\mathrm{a}}$ and $L$ on light use efficiency. Leaf area index in the shrubland ecosystem dominated by the secondary successional species Leptospermum scoparium J.R. et G. Forst (mānuka) and Kunzea ericoides var. ericoides (A. Rich.) J. Thompson (kānuka) is low, but light use efficiency is relatively high (Tab. II). In contrast, leaf area index in the mature mixed conifer-broadleaved forest dominated by Dacrydium cupressinum Sol. ex Lamb. (rimu) is higher than the value at the shrubland site but low nutrient availability results in a very low light use efficiency.

\section{METHODS}

\subsection{Field sites}

The mixed podocarp-broadleaved forest was located at Okarito Forest, Westland (lat. $43.2^{\circ} \mathrm{S}$, long. $170.3{ }^{\circ} \mathrm{E}$, elevation $50 \mathrm{~m}$ above sea level). This lowland terrace forest is dominated ( $72 \%$ of the basal area) by 400 to 600 -year-old Dacrydium trees with a maximum height of $25 \mathrm{~m}$ and an average canopy depth of approximately $10 \mathrm{~m}$. The landform at the site is glacial in origin and the soil taxonomy is described as Entisols that have evolved to Inceptisols or Spodosols [47]. The loess is poorly preserved because of erosion and acid dissolution from extreme leaching resulting from high rainfall [2]. The soils have very low permeability and low porosity and are frequently waterlogged. The soils are extremely acid ( $\mathrm{pH} 3.8-4.4)$ with medium levels of nitrogen $\left(2.1 \mathrm{~mol} \mathrm{~kg}^{-1}\right)$ in the upper $150 \mathrm{~mm}$, falling to very low values $(0.14 \mathrm{~mol} \mathrm{~kg}-1)$ at a depth of $150 \mathrm{~mm}$, and low values of acidextractable phosphorus and low phosphorus retention [37]. The mean annual biomass increment for the site was estimated to be $0.05 \mathrm{~kg} \mathrm{C} \mathrm{m}^{-2}$ [58] and the effective leaf area index (half-total surface area basis) was 3.5. Average foliage nitrogen concentration was $128 \mathrm{mmol} \mathrm{m}^{-2}$ [50].

Average daily values of air temperature and air saturation deficit were available from a station located $20 \mathrm{~km}$ south of the site and daily values of solar radiation were available from a station located $100 \mathrm{~km}$ north of the forest site. Mean annual temperature is $11.3^{\circ} \mathrm{C}$ with a small range between winter and summer of $8.6^{\circ} \mathrm{C}$ and annual rainfall is approximately $3400 \mathrm{~mm}$. Further details of the site can be found in Whitehead et al. [58].

The shrubland site was located in the Tongariro National Park, central North Island, New Zealand (latitude $39.5^{\circ} \mathrm{S}$, longitude $175.8^{\circ} \mathrm{E}$, elevation $800 \mathrm{~m}$ above sea level), comprising dense shrubland vegetation dominated by $L$. scoparium and $K$. ericoides resulting from regrowth after burning approximately 39 years previously. The stand consisted of approximately 1.4 stems $\mathrm{m}^{-2}$ of Leptospermum trees and 1.0 stems $\mathrm{m}^{-2}$ of Kunzea trees. Average tree height ( \pm standard error) was $5.0 \pm 0.1 \mathrm{~m}$ and average canopy depth was $1.7 \pm 0.3 \mathrm{~m}$. The soil is classified as Podzolic Orthic Pumice soils of the Rangipo series [21], roughly similar to the Vitrands classification in the USDA soil taxonomy series [47] and low average nitrogen concentration to a depth of $300 \mathrm{~mm}$ of $0.17 \mathrm{~mol} \mathrm{~kg}^{-1}$ [45]. The estimate of mean annual biomass increment for the site was $0.22 \mathrm{~kg} \mathrm{C} \mathrm{m}^{-2}$ and the estimate of leaf area index (half-total surface area basis) was 2.8. Average foliage nitrogen concentration was $125 \mathrm{mmol} \mathrm{m}^{-2}$ [59] and there were no significant differences between the species or with depth in the canopy.

Long-term mean annual temperature at the nearest weather station at Turangi ( $17 \mathrm{~km}$ away from the site) was $12.0^{\circ} \mathrm{C}$ and mean annual rainfall was $1586 \mathrm{~mm}$ [38]. The temperature data were extrapolated to the field site assuming a wet adiabatic lapse rate and rainfall was adjusted orographically based on comparisons of meteorological data from stations located at different elevations (J.D. White, personal communication). Further details of the site can be found in Whitehead et al. [59]. 
Table III. Values of parameters used in the model to estimate annual net carbon uptake at the two field sites. The parameters shown are maximum values for foliage in the upper canopies and are estimated from measurements made at a base temperature of $20^{\circ} \mathrm{C}$.

\begin{tabular}{|c|c|c|c|c|}
\hline Parameter & Definition & D. cupressinum & $\begin{array}{l}\text { L. scoparium } \\
\text { K. ericoides }\end{array}$ & Units \\
\hline$\overline{V_{\mathrm{cmax}}}$ & Maximum rate of carboxylation & 12 & 60 & $\mu \mathrm{mol} \mathrm{m} \mathrm{m}^{-2} \mathrm{~s}^{-1}$ \\
\hline$J_{\max }$ & Apparent maximum rate of electron transport & 32 & 120 & $\mu \mathrm{mol} \mathrm{E} \mathrm{m} \mathrm{m}^{-2} \mathrm{~s}^{-1}$ \\
\hline$R_{l 0}$ & Light-independent rate of respiration & 0.7 & 1.5 & $\mu \mathrm{mol} \mathrm{m} \mathrm{m}^{-2} \mathrm{~s}^{-1}$ \\
\hline$\alpha$ & Quantum yield of electron transport & 0.22 & 0.24 & mol E mol quanta ${ }^{-1}$ \\
\hline$\beta$ & Convexity of the light response curve & 0.66 & 0.71 & \\
\hline$a$ & Coupling parameter related to intercellular $\mathrm{CO}_{2}$ concentration & 4.0 & 4.2 & \\
\hline$g_{\mathrm{sc} 0}$ & Residual stomatal conductance to $\mathrm{CO}_{2}$ transfer & 10 & 10 & $\mathrm{mmol} \mathrm{m} \mathrm{m}^{-2} \mathrm{~s}^{-1}$ \\
\hline$D_{\mathrm{s} 0}$ & Sensitivity of stomatal conductance to air saturation deficit $D$ & 8.9 & 11.6 & $\mathrm{mmol} \mathrm{mol}^{-1}$ \\
\hline$D_{\text {smin }}$ & Minimum value of $D$ for decreasing $g_{\mathrm{sc}}$ & 5.0 & 4.5 & $\mathrm{mmol} \mathrm{mol}^{-1}$ \\
\hline$l$ & Foliage dimension & 1 & 3 & $\mathrm{~mm}$ \\
\hline$W_{\max }$ & Root-zone water storage capacity & 36 & 72 & $\mathrm{~mm}$ \\
\hline
\end{tabular}

\subsection{The canopy model}

A one-dimensional, multi-layer canopy model incorporating radiative transfer, energy balance, evaporation and canopy photosynthesis [32], and water balance [57] was used to explore the consequences of changing leaf area index and foliage nitrogen concentration on net annual carbon uptake for the canopy at the two sites. The model has been described fully elsewhere [58-61], so only brief details will be provided here. The canopy was divided into 20 layers based on the vertical distribution of cumulative canopy leaf area index. Leaf energy balance and the coupling of photosynthesis with stomatal conductance [30] are used to calculate photosynthesis for sunlit and shaded foliage separately in each layer [32]. Total photosynthesis is summed across layers within the canopy and daily values are obtained using Gaussian integration following Gourdriaan and van Laar [16].

Photosynthesis, $A$, for sunlit and shaded foliage in each layer is calculated as the minimum of the rates limited by the carboxylation, $A_{\mathrm{c}}$, and electron transport, $A_{\mathrm{q}}$, such that

$$
A=\min \left\{A_{c}, A_{q}\right\}-R_{l}
$$

where $R_{l}$ is the rate of light-independent respiration, $A_{\mathrm{c}}$ is dependent on the maximum rate of carboxylation, $V_{\mathrm{cmax}}$, and $A_{\mathrm{q}}$ is dependent on the response of the rate of electron transport, $J$, to irradiance and its maximum value at saturating irradiance, $J_{\max }[12,13]$. Values for the parameters describing the dependence of $V_{\mathrm{cmax}}$ and $J_{\max }$ on temperature were taken from Benecke et al. [3] with the form of the response described by Walcroft et al. [55]. Photosynthesis is also coupled with stomatal conductance and the response of conductance to air saturation deficit following Leuning [30]. The response of foliage respiration to temperature is described by an Arrhenius function used previously by Turnbull et al. [52, 53]. Leaf temperature is estimated from air temperature using energy balance calculations and the characteristic foliage dimension following Leuning et al. [32].

The model incorporates water balance and the limiting effects of seasonal root-zone water deficit on canopy photosynthesis [57]. On wet days, the proportion of net rainfall penetrating the canopy is set at 0.8 (R.J. Jackson, personal communication) and transpiration and understorey and soil evaporation are reduced from their potential values by $25 \%$. The root-zone water storage capacity of the soil was estimated from measurements of root-zone depth and soil texture at the two sites. Daily calculations of water balance, including components of transpiration from the tree canopy, evaporation from the wet tree canopy, and evaporation from the understorey vegetation and soil, are used to define a coefficient to reduce canopy photosynthesis when daily root-zone water storage fell below $50 \%$ of its maximum value.
Daily weather data required to drive the model are solar irradiance, minimum and maximum air temperature and rainfall, with hourly values of irradiance, temperature and air saturation deficit calculated following Goudriaan and van Laar [16]. The eleven parameters required for the model are defined in Table III.

\subsection{Modelling procedure}

Values for the parameters required for the model were taken from [58] for the Dacrydium site and [59] for the Leptospermum/Kunzea site and are listed in Table III. Daily weather data were used for 1 year with the model to estimate annual net canopy photosynthesis, $A$, and annual night-time respiration, $R_{\mathrm{d}}$, for the actual conditions at both sites. Seasonal variability in $A$ and $R_{\mathrm{d}}$ for the two sites has been reported previously [58-61] and will not be discussed in detail in this paper. Two types of simulations were then applied to the base conditions to simulate the effects of changing fertility. Leaf area index was decreased or increased by 25 and 50\% uniformly with depth through the profile and the model was rerun with no changes in values for the parameters. Foliage nitrogen concentration per unit area, $N_{\mathrm{a}}$, was then increased or decreased by 25 or $50 \%$, resulting in changes to the values for the parameters $V_{\mathrm{cmax}}, J_{\max }$, and respiration at base temperature, $R_{l 0}$. Values for the other parameters were held constant. Changes in annual canopy values of $A$ and $R_{\mathrm{d}}$ were expressed as proportions of the values for the canopies in the actual conditions.

The relationships of $V_{\mathrm{cmax}}$ and $J_{\max }$ with changing foliage nitrogen concentration, $N_{\mathrm{a}}$, for Leptospermum/Kunzea were taken from measurements made at the field site (Fig. 1) and described previously [59]. Foliage nitrogen concentrations for Dacrydium at the field site were low [50] and the range in values was small (Fig. 1), so it was not possible to use these to derive the response of photosynthetic parameters to $N_{\mathrm{a}}$. Instead, slopes of the relationships (but not the actual values) for $V_{\mathrm{cmax}}$ and $J_{\max }$ and $N_{\mathrm{a}}$ for the conifer Pinus radiata $\mathrm{D}$. Don from [55] were adopted (Fig. 1). Proportional changes in values for $V_{\mathrm{cmax}}$ and $J_{\max }$ at different foliage nitrogen concentrations used in the model were applied to the actual base value for Dacrydium. For all simulations, it was assumed that changes in the rate of respiration at base temperature, $R_{l 0}$, were closely associated with changes in $V_{\text {cmax }}$ [32]. Based on measurements at the field sites it was assumed that $R_{l 0}=0.06 V_{\text {cmax }}$ for Dacrydium [50] and $R_{l 0}=0.025 V_{\text {cmax }}$ for Leptospermum/Kunzea [59].

The final simulation was chosen to represent a realistic response of the canopy to an increase in nitrogen availability. Values for $L$ and foliage nitrogen concentration per unit area, $N_{\mathrm{a}}$ were increased together by 50 and $20 \%$ respectively and the resulting values of $V_{\mathrm{cmax}}$ 
and $J_{\max }$ were used to simulate these effects on annual net canopy photosynthesis. For the canopy, this simulation was equivalent to increasing the total amount of nitrogen by $80 \%$. Estimates of the vertical profiles of photosynthesis through the canopies from the model are presented to interpret the processes limiting canopy net carbon uptake.

\section{RESULTS}

\subsection{Independent changes in $N_{\mathrm{a}}$ and $L$}

Increasing or decreasing leaf area index, $L$, up to $50 \%$ from the actual value for each site resulted in a smaller than proportional effects on absorbed irradiance, $Q_{\mathrm{a}}$ (Fig. 2). Reductions in $Q_{\mathrm{a}}$ resulting from decreasing $L$ by $50 \%$ were greater (maximum $27 \%$ for Dacrydium) than increases in $Q_{\mathrm{a}}$ resulting from an equivalent increase in $L$ (maximum $10 \%$ for Dacrydium). The effects of changes in $L$ on annual canopy net photosynthesis, $A$, were proportionately close to those resulting from similar changes in $N_{\mathrm{a}}$ with the effects of decreasing $N_{\mathrm{a}}$ and $L$ being more pronounced (maximum $35 \%$ for Dacrydium) than equivalent increases (maximum $13 \%$ for Dacrydium). Canopy net photosynthesis with increasing $N_{\mathrm{a}}$ and $L$ was increased more favourably for Dacrydium (maximum 13\%) than for Leptospermum/Kunzea (maximum 9\%). However, a $50 \%$ reduction in $N_{\mathrm{a}}$ resulted in a more pronounced effect on Leptospermum/Kunzea (34\%) than on Dacrydium (29\%), while a $50 \%$ reduction in $L$ reduced $A$ more in Dacrydium (35\%) than in Leptospermum/Kunzea ( $31 \%$ ). The effects of changing $L$ on the ratio of $A$ to $Q_{\mathrm{a}}$ to give gross light use efficiency, $\varepsilon_{\text {gross }}$, was very small, except when $L$ was reduced by $50 \%, \varepsilon_{\text {gross }}$ decreased by $10 \%$ at the Leptospermum/Kunzea site and $12 \%$ at the Dacrydium site (Fig. 3). In contrast, $\varepsilon_{\text {gross }}$ increased, but non-linearly, with increasing foliage nitrogen concentration.

Changing $L$ resulted in a linear effect on integrated foliage respiration, $R_{\mathrm{d}}$, for both species but the slope of the response was much steeper for Leptospermum/Kunzea than for Dacrydium (Fig. 2). A $50 \%$ change in $N_{\mathrm{a}}$ in Leptospermum/ Kunzea resulted in a $50 \%$ change in $R_{\mathrm{d}}$, but the change for

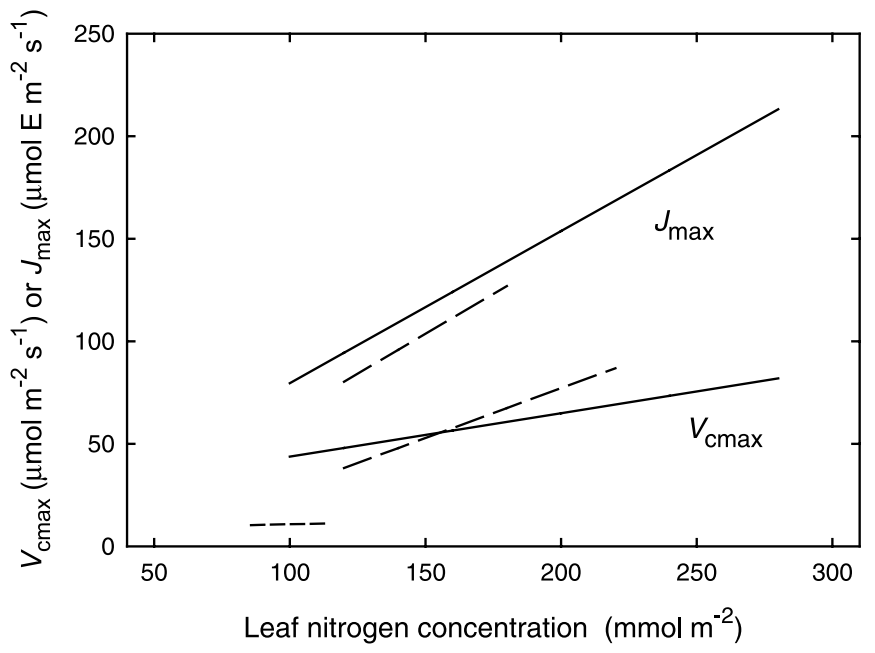

Figure 1. Relationships between the maximum rate of carboxylation, $V_{\text {cmax }}$, and the apparent maximum rate of electron transport at saturating irradiance, $J_{\max }$, and foliage nitrogen concentration per unit area, $N_{\mathrm{a}}$, for Pinus radiata (solid lines) [55] and Leptospermum/Kunzea seedlings (dashed lines) [59]. The data shown by the short dashed line are for Dacrydium [50]. The regression equations for the lines shown are $V_{\mathrm{cmax}}=0.212 N_{\mathrm{a}}+11.26$ and $J_{\max }=0.742 N_{\mathrm{a}}+2.668$ for Pinus radiata and $V_{\mathrm{cmax}}=0.487 N_{\mathrm{a}}-20.29$ and $J_{\max }=0.777 N_{\mathrm{a}}-$ 12.96 for L. eptospermum/Kunzea. The slopes of the lines for Pinus radiata were used to represent the proportional responses for Dacrydium as described in the text.

Dacrydium was only $25 \%$. These resulting effects on $R_{\mathrm{d}}$ were more pronounced than the equivalent effects of changing $N_{\mathrm{a}}$ and $L$ on $A$. The resulting effects of net light use efficiency, $\varepsilon_{\text {net }}=\left(A-R_{\mathrm{d}}\right) / Q_{\mathrm{a}}$, were similar for the two canopies with changes in $L$, but the responses were different with changes in $N_{\mathrm{a}}$ (Fig. 3). Maximum values of $\varepsilon_{\text {net }}$ at both sites occurred with a $25 \%$ reduction in $L$ and, at high values of $L, \varepsilon_{\text {net }}$ decreased below the actual value. For Dacrydium, $\varepsilon_{\text {net }}$ increased with increasing $N_{\mathrm{a}}$. In contrast, the maximum value of $\varepsilon_{\text {net }}$ occurred for the actual conditions at the Leptospermum/Kunzea site.

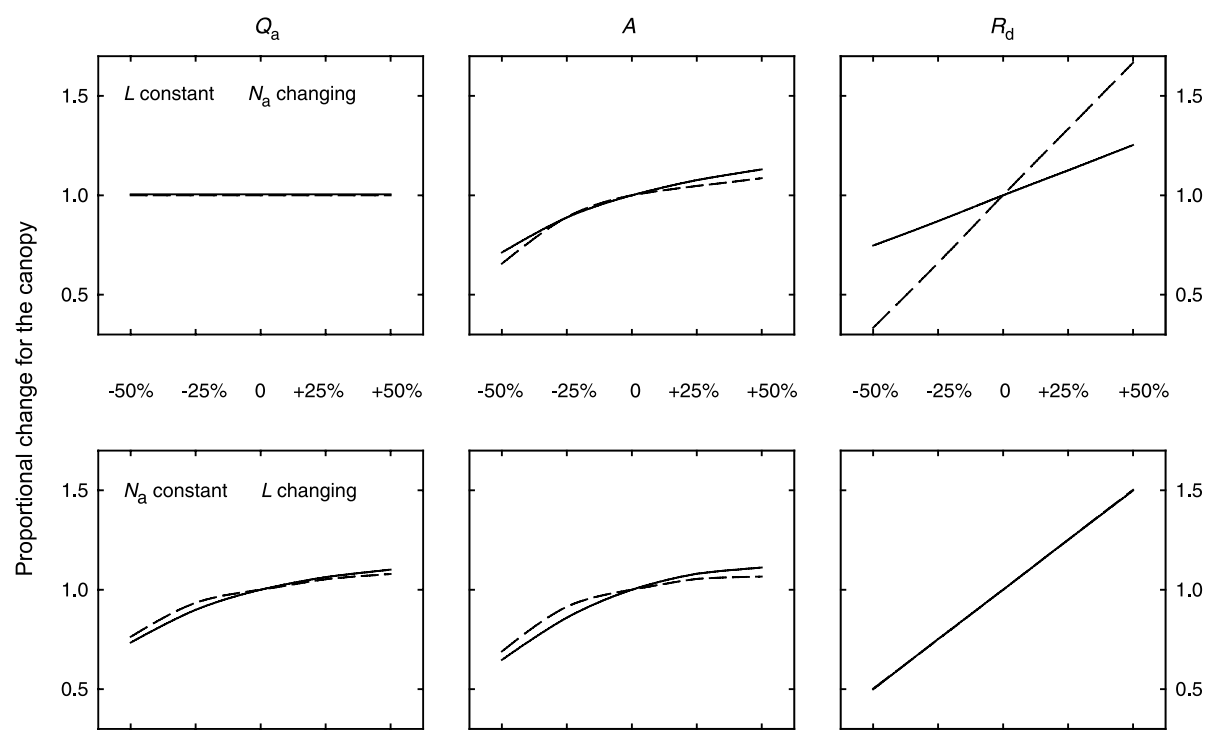

Figure 2. Proportional change in annual absorbed irradiance, $Q_{\mathrm{a}}$, canopy photosynthesis, $A$, and night-time respiration, $R_{\mathrm{d}}$, for the Dacrydium (solid lines) and Leptospermum/Kunzea (dashed lines) canopies in response to changes in foliage nitrogen concentration, $N_{\mathrm{a}}$, with constant leaf area index, $L$, (upper panels) and changes in $L$ with $N_{\mathrm{a}}$ constant (lower panels). Changes in $N_{\mathrm{a}}$ and $L$ are indicated as $\pm 50 \%$ and $\pm 25 \%$ from the actual values shown as zero change. 

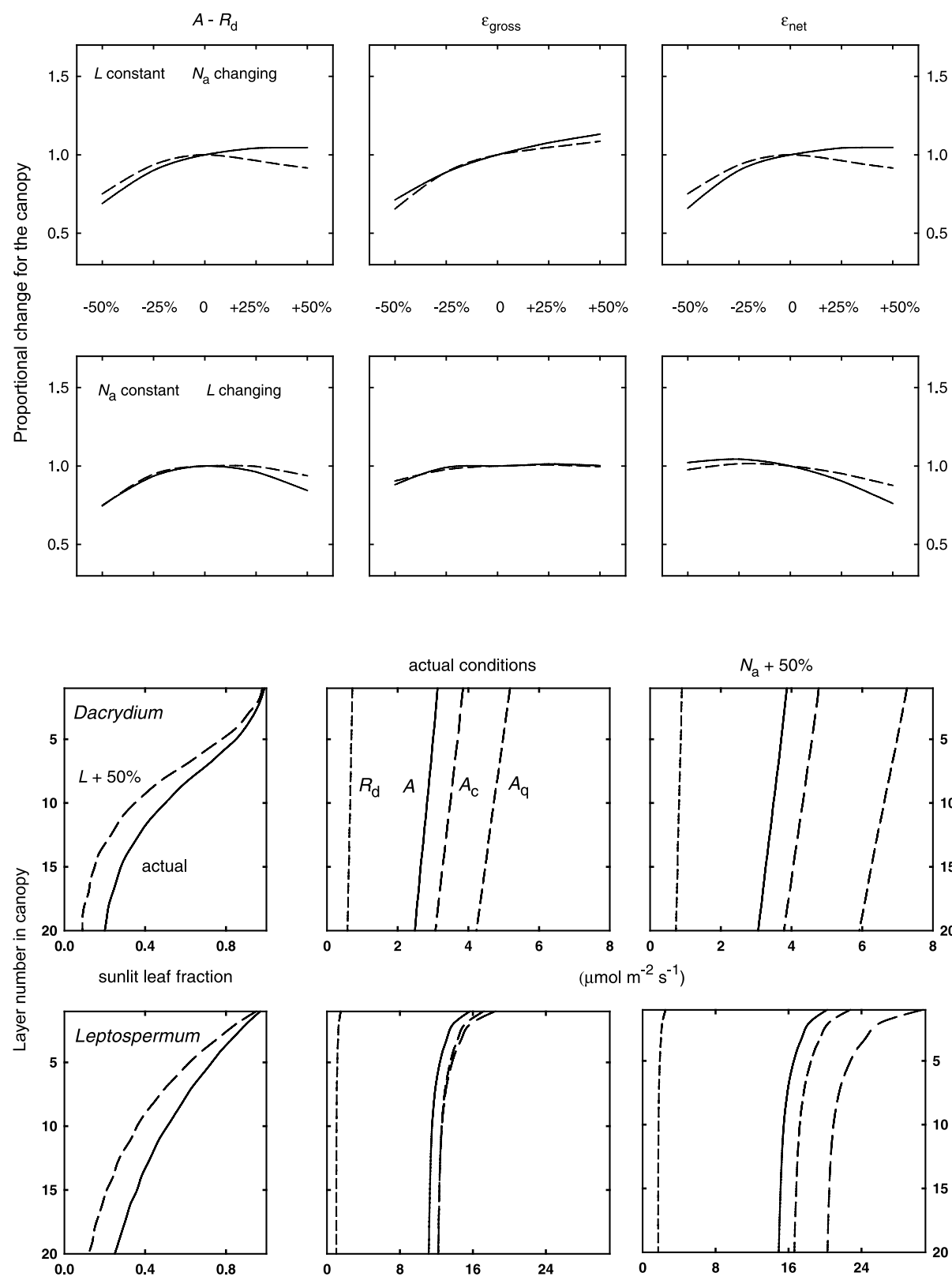
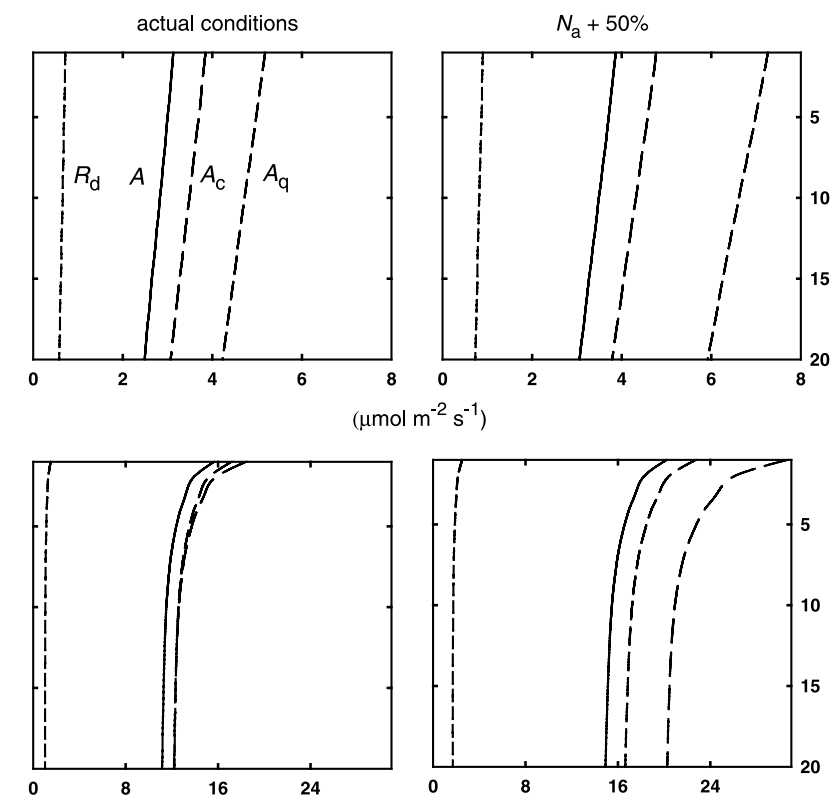

Figure 4. Vertical distribution through 20 canopy layers of the sunlit leaf fraction and components of photosynthesis for sunlit foliage for Dacrydium (upper panels) and Leptospermum/Kunzea (lower panels). The panels on the left show the changes in sunlit leaf fraction for the actual conditions (solid lines) and with an increase in leaf area index, $L$, of $50 \%$ (dashed lines). The panels in the centre show the actual conditions for the canopies and the panels on the right show the effects of an increase in foliage nitrogen concentration, $N_{\mathrm{a}}$, of $50 \%$. The components of photosynthesis shown are the rate limited by carboxylation (long dashed lines), $A_{\mathrm{c}}$, the rate limited by electron transport (medium dashed lines), $A_{\mathrm{q}}$, and the rate of light-independent respiration (short dashed lines), $R_{\mathrm{d}} . A$ is the actual rate of photosynthesis (solid lines) as given by equation (1). The conditions used in the calculations are typical for a bright day in summer with incident irradiance $(400-700 \mathrm{~nm}) 1000 \mathrm{~W} \mathrm{~m}^{-2}$, diffuse fraction 0.2 , solar elevation $75^{\circ}$, air temperature $20^{\circ} \mathrm{C}$, and air saturation deficit $1 \mathrm{kPa}$.

\subsection{Vertical profiles of photosynthesis through the canopies}

The sunlit leaf fraction decreased at all depths through the canopies at both sites when $L$ was increased by $50 \%$ in the model, although the decrease was less pronounced in the top half of the Dacrydium canopy compared with the Leptospermum/Kunzea canopy (Fig. 4). For typical midday conditions in summer, rates of photosynthesis, $A$, for sunlit foliage were higher at all depths in the Leptospermum/Kunzea canopy when compared with values at equivalent depths in the Dacrydium canopy. For Dacrydium, rates of photosynthesis for sunlit foliage decreased linearly with depth. But, for Leptospermum/
Kunzea, photosynthesis was high for sunlit foliage in the upper canopy layers and lower, but constant, in layers lower in the canopy. At all depths, photosynthesis for sunlit Dacrydium foliage in the actual canopy conditions was strongly limited by the rate of carboxylation, $A_{\mathrm{c}}$. Although $A_{\mathrm{q}}, A_{\mathrm{c}}$ and $A$ were increased at all canopy depths in the simulation when $N_{\mathrm{a}}$ was increased by $50 \%$, photosynthesis remained strongly limited by the rate of carboxylation. In the actual Leptospermum/Kunzea canopy, photosynthesis was co-limited by the rates of carboxylation and electron transport, except in the top five layers that were limited marginally by electron transport. An increase in $N_{\mathrm{a}}$ by $50 \%$ resulted in increased rates of $A_{\mathrm{c}}$ and $A_{\mathrm{q}}$ and a clear limitation to photosynthesis by electron transport. 

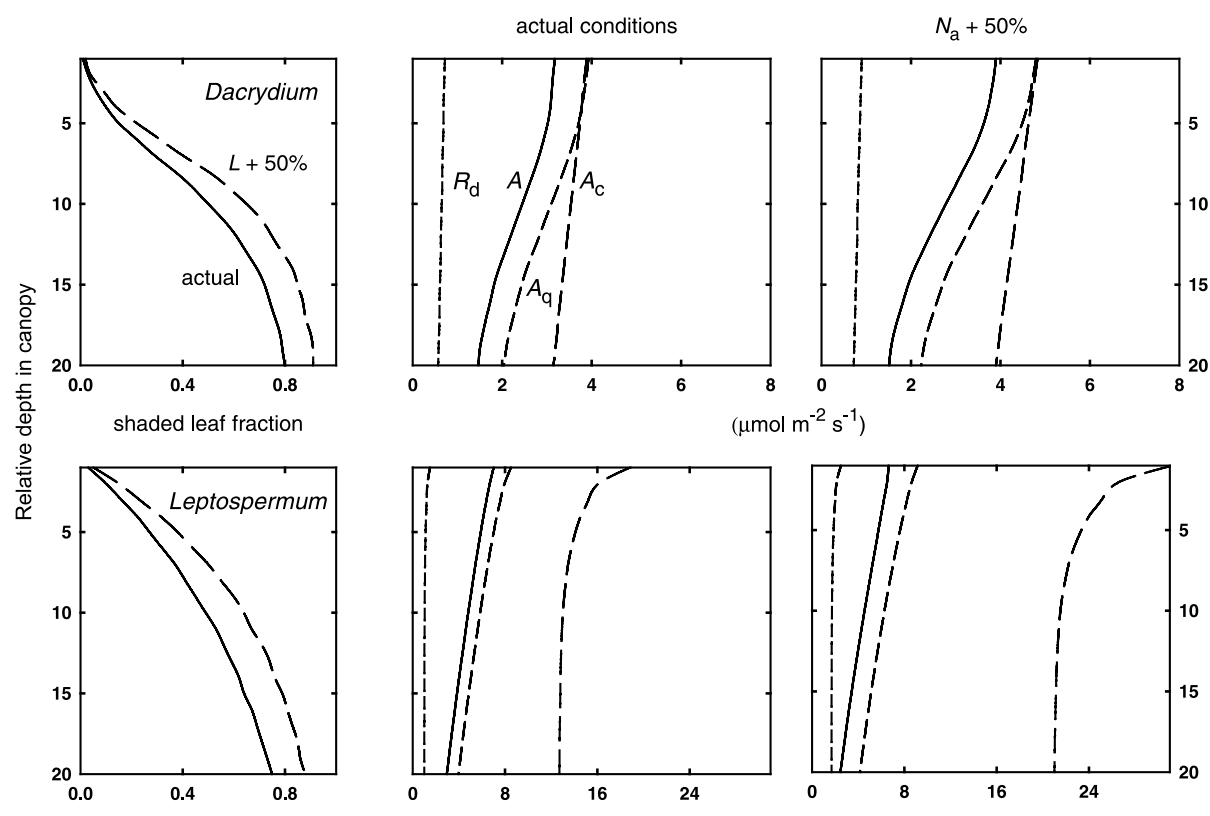

Figure 5. Vertical distribution through 20 canopy layers of the shaded leaf fraction (1-sunlit leaf fraction) and components of photosynthesis for shaded foliage for Dacrydium (upper panels) and Leptospermum / Kunzea (lower panels). The panels on the left show the changes in shaded leaf fraction for the actual conditions (solid lines) and with an increase in leaf area index, $L$, of $50 \%$ (dashed lines). The panels in the centre show the actual conditions for the canopies and the panels on the right show the effects of an increase in foliage nitrogen concentration, $N_{\mathrm{a}}$, of $50 \%$. The symbols shown and the conditions used in the calculations are the same as those in Figure 4.
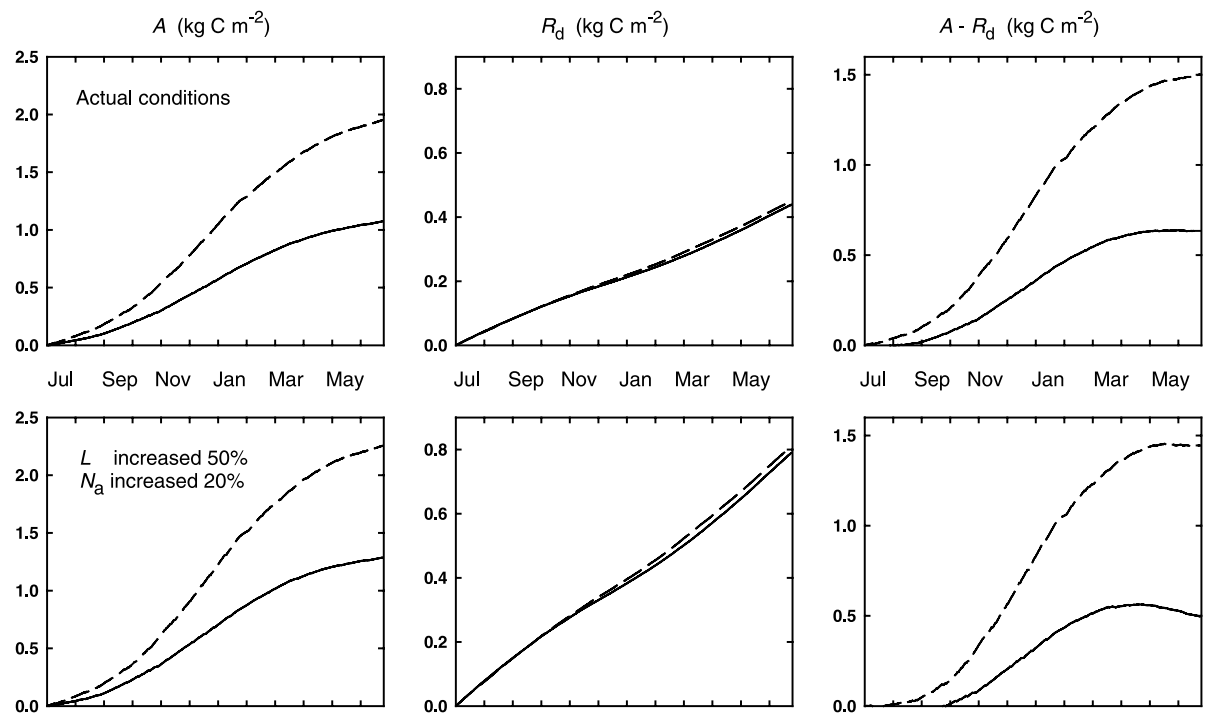

Figure 6. Seasonal cumulative canopy photosynthesis, $A$, night-time respiration, $R_{\mathrm{d}}$, and the difference $A-R_{\mathrm{d}}$ for the Dacrydium (solid lines) and Leptospermum/Kunzea (dashed lines) canopies. The upper panels show the actual conditions for the canopies and the lower panels show the results of a simulation where leaf area index, $L$, is increased by $50 \%$ and foliage nitrogen concentration, $N_{\mathrm{a}}$, is increased by $20 \%$.

Photosynthesis in shaded foliage in the Dacrydium canopy was limited by carboxylation rate in the top five layers, then by electron transport in lower layers (Fig. 5). In the Leptospermum/Kunzea canopy, foliage was strongly limited by electron transport in all layers. When $L$ was increased by $50 \%$ in the model, this increased the shaded leaf fraction in all layers in both canopies. Increasing $N_{\mathrm{a}}$ by $50 \%$ increased $A$ in the top layers of the Dacrydium canopy but did not affect rates of photosynthesis at lower layers, or throughout the Leptospermum/Kunzea canopy, as photosynthesis remained limited by the rate of electron transport.

\subsection{Realistic simulation}

For both canopies, maximum rates of canopy net photosynthesis occurred in early spring (October) to midsummer (February) with no periods of pronounced limitation during this time $[58,59]$. Cumulative daily values of canopy photosynthesis showed higher rates throughout the year for the Leptospermum/ Kunzea canopy compared with the Dacrydium canopy (Fig. 6). Following seasonal changes in temperature and day length, maximum respiration rates occurred in spring (September) and autumn (April) with slightly lower rates in late spring (November). Rates were only slightly greater for Leptospermum/Kunzea than for Dacrydium from summer onwards. The rate of net carbon uptake $\left(A-R_{\mathrm{d}}\right)$ for both canopies was at maximum in late spring and summer (November to January), then decreased during autumn (March to June).

The effects of increasing $L$ by $50 \%$ and foliage nitrogen concentration per unit area, $N_{\mathrm{a}}$ by $20 \%$ resulted in small increases in annual net canopy photosynthesis (16\% for Leptospermum/Kunzea, 20\% for Dacrydium) but more marked 
increases in respiration (80\% for both Leptospermum/Kunzea and Dacrydium) compared with the actual conditions for the two canopies. This resulted in slight decreases in the rates of net carbon uptake for both canopies in spring and summer and more marked decreases in autumn (April to June) compared with actual conditions for the two canopies. At the end of the year, annual net carbon uptake for the simulation was lower by $4 \%$ and $22 \%$ for Leptospermum/Kunzea and the Dacrydium canopies, respectively, compared with net uptake for the actual conditions.

\section{DISCUSSION}

The most significant result from the analysis simulating the effects of increasing $L$ by $50 \%$ and foliage nitrogen concentration per unit area, $N_{\mathrm{a}}$ by $20 \%$ is that this led to decreases in net annual carbon uptake, with the decrease larger for the Dacrydium canopy than for the shrubland species (Fig. 6). At both sites, the simulated conditions enhanced canopy photosynthesis substantially, but this was offset by much larger increases in respiration associated with increased foliage area and increased foliage nitrogen concentration. We suggest that this simulation is a realistic possibility for both sites. Our simulated results are dependent on the assumption that there is a constant relationship between the parameters $R_{l 0}$ and $V_{\text {cmax }}$ with changing foliage nitrogen concentration [32]. While there is evidence that the slope of increasing foliage respiration rate with increasing $N_{\mathrm{a}}$ is greater than the slope of the relationship between $V_{\mathrm{cmax}}$ and $N_{\mathrm{a}}[42,43,59]$, an alternative approach would be to change the base rate of respiration in relation to carbon uptake. Support for this approach is provided from the demonstration at the leaf scale of a clear relationship between cumulative night-time respiration and cumulative photosynthesis during the previous day in a Quercus rubra canopy [60]. However, our analysis does serve to highlight the importance of respiration to the annual carbon balance and confirms earlier conclusions using models for conifers elsewhere. Net carbon gain in response to fertiliser application was less than 5\% for Pinus radiata [36] or not detectable for Pinus elliottii [7]. When $L$ in young Pinus taeda was doubled following application of fertiliser, canopy $A$ increased by only $50 \%$ and canopy $R_{\mathrm{d}}$ was increased by $100 \%$ [26].

While the use of multi-layer models for scaling $\mathrm{CO}_{2}$ exchange from leaves to canopies has been well tested in forests $[8,28,63]$, there has generally been much more emphasis on measurements for obtaining parameter values of photosynthesis than those needed for respiration [29]. Our results highlight the need for careful determination of parameter values for respiration in models. Rates of respiration are low compared with photosynthesis but, when integrated over night periods, total respiration becomes large and canopy carbon balance is very sensitive to this [29]. Based on available data, in our model we held the base value of respiration as a constant proportion of $V_{\text {cmax }}$. From the relationships shown in Figure 1, a change in $N_{\mathrm{a}}$ of $50 \%$ led to a change in the base rate of respiration, $R_{l 0}$, of about $25 \%$ for Dacrydium and $50 \%$ for Leptospermum/ Kunzea (Fig. 2). Slopes of the linear response of respiration to foliage nitrogen concentration per unit foliage mass reported for boreal species [42] and Pinus radiata [43] showed that a change in foliage nitrogen concentration of $50 \%$ led to a change in the base rate of respiration, $R_{l 0}$, close to $50 \%$. Our proportional changes in $R_{l 0}$ with $N_{\mathrm{a}}$ were consistent with this. The response of respiration to $N_{\mathrm{a}}$ for Dacrydium was less than that for Leptospermum/Kunzea because of lower values for $V_{\mathrm{cmax}}$. Tissue et al. [50] argue that the low rate of canopy photosynthesis in Dacrydium is, in part, attributable to a high ratio of $R_{l}$ to $A$.

The effects of changes in $N_{\mathrm{a}}$ and $L$ on annual $A$ are smaller than the changes in $R_{\mathrm{d}}$ (Fig. 2) because of the non-linear processes of radiative transfer and the response of photosynthesis to irradiance at the leaf scale. Interpretation of the vertical profiles of the components of photosynthesis with changes in $N_{\mathrm{a}}$ and $L$ is useful to explain the simulated responses in canopy photosynthesis and light use efficiency. For typical midday conditions on a summer day, low values of $V_{\text {cmax }}$ in the Dacrydium canopy resulted in photosynthesis for sunlit foliage being limited strongly by the rate of carboxylation in all layers, even when $N_{\mathrm{a}}$ was increased by $50 \%$ (Fig. 4). In contrast, photosynthesis for sunlit foliage in the Leptospermum/Kunzea canopy was limited almost equally in all layers by the rates of carboxylation and electron transport. When $N_{\mathrm{a}}$ was increased, the dominant limitation to photosynthesis was the rate of electron transport. The consequence of the relationships between $V_{\text {cmax }}, J_{\max }$, and $N_{\mathrm{a}}$ for the Leptospermum/Kunzea canopy (Fig. 1) is that the ratio $J_{\text {max }}: V_{\text {cmax }}$ increases with increasing $N_{\mathrm{a}}$. Since we assume that $R_{l 0}$ is a constant fraction of $V_{\mathrm{cmax}}$, then with increasing $N_{\mathrm{a}}$, the ratio $R_{l 0}: J_{\max }$ increases. The result is that the increase in the ratio $A: R_{\mathrm{d}}$ is greater when $L$ is increased and $N_{\mathrm{a}}$ held constant than when $L$ is held constant and $N_{\mathrm{a}}$ is increased. Thus, for the Leptospermum/Kunzea canopy, net carbon uptake is enhanced more by an increase in $L$ than by an increase in $N_{\mathrm{a}}$ (Fig. 3). The opposite is true for the Dacrydium canopy because photosynthesis is limited dominantly by the rate of carboxylation, rather than the rate of electron transport.

Strong limitation of photosynthesis by electron transport in the Leptospermum/Kunzea canopy also suggests that photosynthesis would respond more to fluctuations in irradiance than in the Dacrydium canopy. Evidence supporting this conclusion is provided by an analysis of the effects of the fraction of diffuse irradiance on canopy photosynthesis. Canopy photosynthesis in the Dacrydium canopy was much less sensitive to increases in the fraction of diffuse irradiance than a Quercus canopy with photosynthetic properties similar to the Leptospermum/Kunzea canopy [61]. However, it is important to note that the analysis in Figures 4 and 5 is confined to midday conditions in summer, and integration of the dynamic effects of changing sun angle, weather variables, and the fractions of sunlit and shaded foliage on photosynthesis is encapsulated in the overall results in Figure 6.

Canopy net photosynthesis started in late winter (August) but reached maximum rates in late spring (November and December, Fig. 6). The smooth increase in cumulative $A$ throughout the year at both sites confirms the lack of marked seasonal limitations to canopy photosynthesis resulting from, for example, temperature extremes or drought. From late summer (March) onwards, net carbon uptake was reduced because of decreases in photosynthesis associated with lower irradiance but continued rates of respiration. This emphasises the important 
contribution of net carbon uptake in spring and early summer for tree growth [26]. There may be less carbon available for growth in summer and winter when canopy photosynthesis is more offset by respiration or, at sites elsewhere, when other environmental influences, for example drought, limit photosynthesis [34, 49].

In our analysis, net canopy carbon uptake was greater for Leptospermum/Kunzea than for Dacrydium. This is consistent with the difference in rates of biomass accumulation at the sites $[56,59]$. Because of the limited data available, we have concentrated on the relationships of photosynthesis and respiration to changes in foliage nitrogen concentration, rather than other nutrients. However, there is strong evidence that productivity in most indigenous ecosystems in New Zealand is limited by phosphorus, rather than nitrogen supply [40]. It is known that photosynthesis is reduced in young trees growing at low phosphorus supply [6], possibly because of reduced carboxylation activity [35], but more experimental work is required to quantify the interactive effects of nitrogen and phosphorus supply on photosynthesis and respiration at the canopy scale.

\section{CONCLUSION}

Our analysis suggests is that annual $\left(A-R_{\mathrm{d}}\right)$ did not increase with increasing leaf area index at either site, despite a small increase in $\varepsilon_{\text {net }}$ with decreasing $L$ for Dacrydium (Fig. 3 ). Annual $\left(A-R_{\mathrm{d}}\right)$ with changes in foliage nitrogen concentration per unit area, $N_{\mathrm{a}}$ were also highest for the actual conditions for Leptospermum/Kunzea and would be increased only slightly at higher values of $N_{\mathrm{a}}$ for Dacrydium. From this we conclude that there is considerable uncertainty that adding fertiliser to these unmanaged ecosystems will result in increased foliage nitrogen concentration, annual net carbon uptake and thus productivity. This is clearly attributable to the pronounced offset of increased photosynthesis by respiration resulting from increases in leaf area index and foliage nitrogen concentration. The Leptospermum/Kunzea canopy appears to be adjusted to operate at the optimum conditions of $L$ and $N_{\mathrm{a}}$ for maximum net carbon uptake, given the environmental constraints. Despite differences in the processes limiting photosynthesis in the Dacrydium canopy, this is also operating close to its optimum conditions for $L$ and $N_{\mathrm{a}}$, although net carbon uptake would be weakly enhanced if foliage nitrogen concentration were increased or leaf area index reduced. The model we have adopted to scale measurements of photosynthesis and respiration from leaves to canopies is useful to explain differences in the components of net carbon uptake and light use efficiency for canopies. Further, the approach increases confidence in making predictions of productivity for forests and shrublands at a range of site fertilities at the national scale.

Acknowledgements: Funding for this work was provided by the Foundation for Research, Science and Technology, contract number C09X0212, with additional support from INRA and a Manaaki Tangata Fellowship from Landcare Research. The analysis was completed while David Whitehead was undertaking collaborative research at INRA-Bordeaux, Gazinet, France. We are grateful for the facilities provided by INRA and to Denis Loustau for stimulating discussion.
We are also grateful to the organisers of the Secondes Rencontres d'Écophysiologie de l'Arbre, held at La Rochelle, for the invitation to present this contribution at the workshop.

\section{REFERENCES}

[1] Albaugh T.J., Allen H.L., Dougherty P.M., Kress L.W., King J.S., Leaf area and above- and belowground growth responses of loblolly pine to nutrient and water additions, For. Sci. 44 (1998) $317-328$

[2] Almond P.C., Loess, soil stratigraphy and Aokautere ash on late Pleistocene surfaces in south Westland, New Zealand: interpretation and correlation with the glacial stratigraphy, Quat. Int. 34-36 (1996) 163-176.

[3] Benecke U., Nordmeyer A.H., Carbon uptake and allocation by Nothofagus solandri var. cliffortioides Hook. (f.) Poole and Pinus contorta Douglas ex Loudon spp. contorta at alpine and subalpine altitudes, in: Waring R.H. (Ed.), Carbon Uptake and Allocation in Subalpine Ecosystems as a Key to Management, For. Res. Lab., Oregon State Univ., Corvallis, OR, USA, 1982, pp. 9-21.

[4] Bernacchi C.J., Singsass E.L., Pimental C., Portis A.R. Jr., Long S.P., Improved temperature response functions for models of Rubisco-limited photosynthesis, Plant Cell Environ. 24 (2001) 253-259.

[5] Brix H., Ebell L.F., Effects of nitrogen fertilization on growth, leaf area and photosynthesis rate in Douglas-fir, For. Sci. 15 (1969) 189-196.

[6] Conroy J.P., Smillie R.M., Kuppers M., Bevege D.J., Barlow E.W., Chlorophyll a fluorescence and photosynthetic and growth response of Pinus radiata to phosphorus deficiency, drought stress and high $\mathrm{CO}_{2}$, Plant Physiol. 81 (1986) 423-429.

[7] Cropper W.P. Jr., Gholz H.L., Evaluating potential response mechanisms of a forest stand to fertilization and night temperature: a case study using Pinus elliottii, Ecol. Bull. (Copenhagen) 43 (1994) 154-160.

[8] Dang Q.-L., Margolis H.A., Collatz G.J., Parameterization and testing of a coupled photosynthesis-stomatal conductance model for boreal trees, Tree Physiol. 18 (1998) 141-153.

[9] Dungan R.J., Whitehead D., Duncan R.P., Seasonal and temperature dependence of photosynthesis and respiration for two cooccurring broad-leaved tree species with contrasting leaf phenology, Tree Physiol. 23 (2003) 561-568.

[10] Dungan R.J., Whitehead D., McGlone M.S., Allen R.B., Duncan R.P., Simulated carbon uptake for a canopy of two broadleaved tree species with contrasting leaf habit, Funct. Ecol. 18 (2004) 34-42.

[11] Evans J.R., Photosynthesis and nitrogen relationship in leaves of $\mathrm{C}_{3}$ plants, Oecologia 78 (1989) 9-19.

[12] Farquhar G.D., Wong S.C., An empirical model of stomatal conductance, Aust. J. Plant Physiol. 11 (1984) 191-210.

[13] Farquhar G.D., von Caemmerer S., Berry J.A., A biochemical model of photosynthetic $\mathrm{CO}_{2}$ assimilation in leaves of $\mathrm{C}_{3}$ species, Planta 149 (1980) 78-90.

[14] Field C.B., Mooney H.A., The photosynthesis-nitrogen relationship in wild plants, in: Givnish T.J. (Ed.), On the Economy of Plant Form and Function, Cambridge University Press, Cambridge, 1986, pp. 25-56.

[15] Gholz H.L., Vogel S.A., Cropper W.P. Jr., McKelvey K., Ewel K.C., Teskey R.O., Dynamics of canopy structure and light interception in Pinus elliottii stands of north Florida, Ecol. Monogr. 61 (1991) 33-51.

[16] Goudriaan J., van Laar H.H., Modelling Crop Growth Processes, Kluwer, Dordrecht, The Netherlands, 1994, 238 p.

[17] Gough C.M., Seiler J.R., Maier C.A., Short-term effects of fertilization on loblolly pine (Pinus taeda L.) physiology, Plant Cell Environ. 27 (2004) 876-886. 
[18] Gower S.T., Gholz H.L., Nakane K., Baldwin C.F., Production and carbon allocation patterns in pine forests, Ecol. Bull. (Copenhagen) 43 (1994) 115-135.

[19] Grassi G., Meir P., Cromer R., Tompkins D., Jarvis P.G., Photosynthetic parameters in seedlings of Eucalyptus grandis as affected by nitrogen supply, Plant Cell Environ. 25 (2002) 1677-1688.

[20] Griffin K.L., Tissue D.T., Turnbull M.H., Schuster W., Whitehead D., Leaf dark respiration as a function of canopy position in Nothofagus fusca trees grown at elevated $\mathrm{CO}_{2}$ partial pressure for five years, Funct. Ecol. 15 (2001) 497-505.

[21] Hewitt A.E., New Zealand Soil Classification, Landcare Research Science Series 1, Landcare Research, Dunedin, New Zealand, 1993.

[22] Hollinger D.Y., Canopy organisation and foliage photosynthetic capacity in a broad-leaved evergreen montane forest, Funct. Ecol. 3 (1989) 53-62.

[23] Hollinger D.Y., Optimality and nitrogen allocation in a tree canopy, Tree Physiol. 16 (1996) 627-634.

[24] Körner Ch., Bannister P., Mark A.F., Altitudinal variation in stomatal conductance, nitrogen content and leaf anatomy in different plant life forms in New Zealand, Oecologia (Berl.) 69 (1986) 577588.

[25] Kosugi Y., Shibata S., Kobashi S., Parameterization of the $\mathrm{CO}_{2}$ and $\mathrm{H}_{2} \mathrm{O}$ gas exchange of several temperate deciduous broad-leaved trees at the leaf scale considering seasonal changes, Plant Cell Environ. 26 (2003) 285-301.

[26] Lai C.-T., Katul G., Butnor J., Siqueira M., Ellsworth D., Maier C., Johnsen K., McKeand S., Oren R., Modelling the limits on the response of net carbon exchange to fertilization in a south-eastern pine forest, Plant Cell Environ. 25 (2002) 1095-1119.

[27] Landsberg J.J., Coops N.C., Modelling forest productivity across large areas and long periods, Nat. Resour. Model. 12 (1999) 1-28.

[28] Law B.E., Williams M., Anthoni P.M., Baldocchi D.D., Unsworth M.H., Measuring and modelling seasonal variation in carbon dioxide and water vapour exchange of a Pinus ponderosa forest subject to soil water deficit, Glob. Change Biol. 6 (2000) 613-630.

[29] Le Goff N., Granier A., Ottorini J.-M., Peiffer M., Biomass increment and carbon balance of ash (Fraxinus excelsior) trees in an experimental stand in northeastern France, Ann. For. Sci. 61 (2004) $577-588$.

[30] Leuning R., A critical appraisal of a combined stomatal-photosynthesis model for $C_{3}$ plants, Plant Cell Environ. 18 (1995) 339-357.

[31] Leuning R., Scaling to a common temperature improves the correlation between photosynthesis parameters $J_{\max }$ and $V_{\text {cmax }}$, J. Exp. Bot. 48 (1997) 345-347.

[32] Leuning R., Kelliher F.M., de Pury D.G.G., Schulze E.-D., Leaf nitrogen, photosynthesis, conductance and transpiration: scaling from leaves to canopies, Plant Cell Environ. 18 (1995) 1183-2000.

[33] Linder S., Axelsson B., Changes in carbon uptake and allocation patterns as a result of irrigation and fertilization in a young Pinus sylvestris stand, in: Waring R.H. (Ed.), Carbon uptake and allocation in subalpine ecosystems as a key to management, For. Res. Lab., Oregon State Univ., Corvallis, OR, USA, 1982, pp. 38-44.

[34] Linder S., Benson M.L., Meyers B.J., Raison R.J., Canopy dynamics and growth of Pinus radiata, I. Effects of irrigation and fertilization during a drought, Can. J. For. Res. 17 (1987) 1157-1165.

[35] Loustau D., Ben Brahim M., Gaudillère J.-P., Dreyer L., Photosynthetic responses to phosphorus nutrition in two-year-old maritime pine seedlings, Tree Physiol. 19 (1999) 707-715.

[36] McMurtrie R.E., Benson M.L., Linder S., Running S.W., Talsma T., Crane W.J.B., Myers B.J., Water/nutrient interactions affecting the productivity of stands of Pinus radiata, For. Ecol. Manage. 30 (1990) 415-423.
[37] Mew G., Lee R., Investigation of the properties and genesis of west Coast wet land soils, South Island, New Zealand, I, Type localities, profile morphology, and soil chemistry, N. Z. J. Sci., 24 (1981) 1-24.

[38] New Zealand Meteorological Service, Summaries of Climatological Observations to 1980, N. Z. Met. Serv. Misc. Publ. No. 177, 1983.

[39] Nordborg F., Nilsson U., Growth, damage and net nitrogen uptake in Picea abies (L.) Karts, Seedlings, effects of site preparation and fertilisation, Ann. For. Sci. 60 (2003) 657-666.

[40] Richardson S.J., Peltzer D.A., Allen R.B., McGlone M.S., Parfitt, R.L., Rapid development of phosphorus limitation in temperate rainforest along the Franz Josef soil chronosequence, Oecologia 139 (2004) 267-276.

[41] Richardson S.J., Allen R.B., Whitehead D., Carswell F.E., Ruscoe W.A., Platt K.H., Climate and net carbon availability determine temporal patterns of seed production by Nothofagus, Ecology 86 (2005) 972-981.

[42] Ryan M.G., Foliar maintenance respiration of subalpine and boreal trees and shrubs in relation to nitrogen content, Plant Cell Environ. 18 (1995) 765-772.

[43] Ryan M.G., Hubbard R.M., Pongracic S., Raison R.J., McMurtrie, R.E., Foliage, fine-root, woody-tissue and stand respiration in Pinus radiata in relation to nitrogen status, Tree Physiol. 16 (1996) 333-343.

[44] Samuelson L.J., Stokes T., Cooksey T., McLemore P. III., Production efficiency of loblolly pine and sweetgum in response to four years of intensive management, Tree Physiol. 21 (2001) 369-376.

[45] Scott N.A., White J.D., Townsend J.A., Whitehead D., Leathwick J.R., Hall G.M.J., Marden M., Rogers G.N.D., Watson A.J., Whaley P., Carbon and nitrogen distribution and accumulation in a New Zealand scrubland ecosystem, Can. J. For. Res. 30 (2000) 1246-1255.

[46] Snowdon P., Benson M.L., Effects of combinations of irrigation and fertilisation on the growth and above-ground biomass production of Pinus radiata, For. Ecol. Manage. 52 (1992) 87-116.

[47] Soil Survey Staff, Keys to Soil Taxonomy, 6th ed., Soil Conservation Service, US Department of Agriculture, Washington DC, USA, 1994.

[48] Teskey R.O., Gholz H.L., Cropper W.P. Jr., Influence of climate and fertilization on net photosynthesis of mature slash pine, Tree Physiol. 14 (1994) 1215-1227.

[49] Thompson W.A., Wheeler A.M., Photosynthesis by mature needles of field-grown Pinus radiata, For. Ecol. Manage. 52 (1992) 225242.

[50] Tissue D.T., Griffin K.L., Turnbull M.H., Whitehead D., Stomatal and non-stomatal limitations to photosynthesis in four tree species in a temperate rainforest dominated by Dacrydium cupressinum in New Zealand, Tree Physiol. 25 (2005) 447-456.

[51] Trotter C.M., Tate K.R., Saggar S., Scott N.A., Sutherland M.A., A multi-scale analysis of a national terrestrial carbon budget and the effects of land-use change, in: Shiyomi M., Kawahata H., Koizumi H., Tsuda A., Awaya Y. (Eds.), Global Environmental Change in the Ocean and on Land, Terrapub, Tokyo, Japan, 2004, pp. 311341.

[52] Turnbull M.H., Whitehead D., Tissue D.T., Schuster W.S.F., Brown K.G., Engel V.C., Griffin K.L., Photosynthetic characteristics in canopies of Quercus rubra, Quercus prinus and Acer rubrum differ in response to soil water availability, Oecologia 130 (2002) $515-524$

[53] Turnbull M.H., Whitehead D., Tissue D.T., Schuster W.S.F., Brown K.J., Griffin K.L., Scaling foliar respiration in two contrasting forest canopies, Funct. Ecol. 17 (2003) 101-114.

[54] Vose J.M., Allen H.L., Leaf area, stemwood growth, and nutrition relationships in loblolly pine, For. Sci. 34 (1988) 547-563. 
[55] Walcroft A.S., Whitehead D., Silvester W.B., Kelliher F.M., The response of photosynthetic model parameters to temperature and nitrogen concentration in Pinus radiata D. Don., Plant Cell Environ. 20 (1997) 1338-1348.

[56] White J.D., Coops N.C., Scott N.A., Estimates of New Zealand forest scrub biomass from the 3-PG model, Ecol. Model. 131 (2000) 175-190.

[57] Whitehead D., Leathwick J.R., Walcroft A.S., Modeling annual carbon uptake for the indigenous forests of New Zealand, For. Sci. 47 (2001) 66-75.

[58] Whitehead D., Hall G.M.J., Walcroft A.S., Brown K.J., Landsberg J.J., Tissue D.T., Turnbull M.H., Griffin K.L., Schuster W.S.F., Carswell F.E., Trotter C.M., James I.L., Norton D.A., Analysis of the growth of rimu (Dacrydium cupressinum) in south Westland, New Zealand, using process-based simulation models, Int. J. Biometeorol. 46 (2002) 66-75.

[59] Whitehead D., Walcroft A.S., Scott N.A., Townsend J.A., Trotter C.M., Rogers G.D., Characteristics of photosynthesis and stomatal conductance in the shrubland species mannuka (Leptospermum scoparium) and kānuka (Kunzea ericoides) for the estimation of annual canopy carbon uptake, Tree Physiol. 24 (2004) 795-804.
[60] Whitehead D., Griffin K.L., Turnbull M.H., Tissue D.T., Engel V.C., Brown K.J., Schuster W.F.S., Walcroft A.S., Response of total night-time respiration to differences in total daily photosynthesis for leaves in a Quercus rubra L. canopy: Implications for modelling canopy $\mathrm{CO}_{2}$ exchange, Glob. Change Biol. 10 (2004) 925-938.

[61] Whitehead D., Walcroft A.S., Griffin K.L., Tissue D.T., Turnbull M.T., Engel V., Brown K.J., Schuster W.S.F., Scaling carbon uptake from leaves to canopies: insights from two forests with contrasting properties, in: Mencuccini M., Grace J., Moncrieff J., McNaughton K.G. (Eds.), Forests at the Land-Atmosphere Interface, CABI Publishing, Wallingford, UK, 2004, pp. 231-254.

[62] Wilson K.B., Baldocchi D.D., Hanson P.J., Spatial and seasonal variability of photosynthetic parameters and their relationship to leaf nitrogen in a deciduous forest, Tree Physiol. 20 (2000) 565578.

[63] Wilson K.B., Baldocchi D.D., Hanson P.J., Leaf age affects the seasonal pattern of photosynthetic capacity and net ecosystem exchange of carbon in a deciduous forest, Plant Cell Environ. 24 (2001) 571-583.

[64] Wullschleger S.D., Biochemical limitations to carbon assimilation in $\mathrm{C}_{3}$ plants - A retrospective analysis of the $A / c_{\mathrm{i}}$ curves for 109 species, J. Exp. Bot. 44 (1993) 907-920. 